\title{
ARTICLE
}

\section{Increased larval survival of Seriola lalandi using Pseudoalteromonas sp. as probiotics}

\author{
Aumento de la sobrevivencia de larvas de Seriola lalandi usando \\ Pseudoalteromonas sp. como probióticos
Yanett Leyton $^{1}$, Camila Sayes ${ }^{1}$, Cristian Mejias ${ }^{1}$, Marcelo Abarca ${ }^{2}$, Rodolfo Wilson ${ }^{2}$ and Carlos Riquelme ${ }^{1}$

\begin{abstract}
${ }^{1}$ Laboratorio Mesocosmos Marino, Centro Bioinnovación de Antofagasta (CBIA), Facultad de Ciencias del Mar y Recursos Biológicos, Universidad de Antofagasta, Box 170, Antofagasta, Chile. yanett.leyton@uantof.cl

${ }^{2}$ Unidad de cultivo de peces, Facultad de Ciencias del Mar y Recursos Biológicos, Universidad de Antofagasta, Box 170, Antofagasta, Chile

Resumen.- La demanda mundial de alimentos aumenta el interés en el desarrollo de la acuicultura. En Chile se están haciendo esfuerzos significativos para desarrollar el cultivo de Seriola lalandi, debido a la alta demanda de su carne a nivel nacional e internacional. Sin embargo, esta especie plantea dificultades persistentes con respecto a la sobrevivencia de las larvas. EI objetivo del presente estudio fue evaluar los efectos de la bacteria Pseudoalteromonas sp. como un suplemento probiótico en el cultivo de larvas de S. Ialandi. Para esto, larvas de S. lalandi se alimentaron con rotíferos (Brachionus rotundiformis y Brachionus plicatilis) y Artemia sp. que se cultivaron previamente usando microalgas mezclado con Pseudoalteromonas sp. Rotíferos y artemias fueron buenos vectores de probióticos debido a que las larvas de S. lalandi alimentadas con suplemento probiótico presentaron mayor sobrevivencia y longitud que el control al final del experimento. Estos hallazgos ponen en evidencia que los probióticos de Pseudoalteromonas sp. son buenos candidatos para el uso en cultivos de larvas de S. lalandi. Sin embargo, se necesita más investigación en una escala de cultivo mayor para validar su uso a nivel comercial.
\end{abstract}

Palabras clave: Pseudoalteromonas sp., probióticos, alimentos vivos, Seriola lalandi, sobrevivencia

\begin{abstract}
Global demand for food increases the interest in develop of aquaculture. Significant efforts are being made in Chile to develop Seriola lalandi culture, because of the high demand of this fish meat at national and international level. However, this species poses persisting difficulties regarding larval survival. The objective of the present study was to evaluate the effects of Pseudoalteromonas sp. bacteria as a probiotic supplement on the larval culturing of S. lalandi. For this, S. lalandi larvae were fed rotifers (Brachionus rotundiformis and Brachionus plicatilis) and Artemia sp. that were previously cultured using microalgae mixed with Pseudoalteromonas sp. Rotifers and Artemia were good probiotics vectors because S. lalandi larvae fed probiotic supplement showed higher survival that the control. These findings evidence that Pseudoalteromonas sp. are good probiotic candidates for use in S. lalandi larval cultures. However, is needed more research on major scale cultivation to validate their use commercially.
\end{abstract}

Key words: Pseudoalteromonas sp., probiotics, live food, Seriola lalandi, survival

\section{INTRODUCTION}

The fish Seriola lalandi (Valenciennes, 1833) has been recognized as having high potential for aquaculture in Chile (Fernández et al. 2015). The cultivation of this species in the larval stage has faced problems such as diseases (deformities) and mortalities. Survival obtained in the culture fluctuates between 1-2.5\% (Avilés \& Castelló 2004), this hindered the development of the industry. Among other variables, the main causes are attributed to nutritional deficiencies of the food, high density of the culture, and susceptibility to diseases in culture conditions. However, the incubation phase of this species must overcome this problem to ensure a sustainable production system in the future.
Probiotics can be defined as live microorganisms that orally administered can be beneficial to the host (Newaj-Fyzul \& Austin 2015). Probiotic use in the aquaculture industry is currently seen as a sustainable and promising strategy not only in the treatment of diseases, but also in terms of fish nutrition, growth, and immunity (Lazado et al. 2014). Probiotics positively promote fish growth, reproduction, nutrient digestion, and stress tolerance, in addition to playing roles in inhibiting pathogens and bettering water quality, among other benefits (Martinez et al. 2012). In fish, Lobo et al. (2014a) suggest that proper nutrition during the first larval stages is important for successful cultivation, and that probiotic supplements contribute towards managing the stress of weaning. 
Based on this information, the use of probiotic food supplements during the larval phase of $S$. lalandi could be a viable alternative for increasing survival rates and nutritional quality. Species within the bacterial from the genus Pseudoalteromonas present probiotic potential for different farmed organisms. For example, Pseudoalteromonas strains isolated from turbot (Psetta maxima L.) larvae are able to reduce the larval mortality of this fish species (Hjelm et al. 2004). Furthermore, Pseudoalteromonas sp. isolated from the intestinal tract of Atlantic cod (Gadus morhua L.) demonstrate antagonistic activities against the pathogen Vibrio anguillarum (Fjellheim et al. 2010). Research in sea cucumbers (Apostichopus japonicus) fed for 45 days with a diet supplemented by Pseudoalteromonas sp. FC228, evidenced improved digestive enzyme activity, thereby stimulating the immune response and providing greater resistance to Vibrio splendidus infection.

In fish feed, live rotifers and Artemia are good vectors for probiotics. For example, Jamali et al. (2015) evaluated the effects of adding the probiotics Bacillus licheniformis and Bacillus subtilis (at $1 \times 10^{6} \mathrm{CFU} \mathrm{mL}^{-1}$ ) in the rotifer Brachionus plicatilis and Artemia urmiana cultures. Jamali et al. (2015) subsequently observed increased growth and higher survival rates Litopenaeus vannamei larvae, where individuals fed a probiotic supplemented diet obtained larger lengths, weights, and survival rates than the shrimp not probiotics fed. Likewise Garcés et al. (2015) found that encapsulating the Lactobacillus pentosus H16 probiotic in Artemia franciscana resulted in no deleterious effects for $A$. franciscana but did inhibit the pathogenic activity of Vibrio alginolyticus $03 / 8525$.

Considering the beneficial potential of probiotics, the present study evaluated the survival of $S$. lalandi larvae fed with rotifers and Artemia previously given probiotic Pseudoalteromonas sp. bacteria. The objective of this research was to find a solution to the high rates of $S$. lalandi larval mortality under hatchery conditions, a situation that increases the production costs of this aquaculture candidate species.

\section{MATERIALS AND METHODS}

\section{SElection of Microalgae AND PROBIOTIC BaCteria}

The microalgae use for both live feed (rotifers) and larvae 'green water' was Nannochloropsis gaditana and the bacterium Pseudoalteromonas sp. (SLP1), previously isolated from the gonads of S. lalandi (Sayes et al. 2016). Both microorganisms were obtained from the strain collection of the laboratory, were selected due to its good fatty acid profile and easy management under culture conditions (microalgae) and, due to its probiotic properties (bacteria), such as antibacterial effects against the pathogen Yersinia ruckeri and a lack of haemolytic, proteolytic, and lipolytic activities (Sayes et al. 2016).

\section{Evaluation of rotifers as PROBIOtIC VECTORS}

Photobioreactors (25 L) which were initially manufactured for benthic microalgae cultivation according to described in Silva-Aciares \& Riquelme (2008), they were conditioned for cultivating rotifers and they were equipped with air pumps and heaters, were filled with seawater filtered $(0.2 \mu \mathrm{m})$, chlorinated $\left(1 \mathrm{~g} \mathrm{~L}^{-1}\right)$ and neutralized with thiosulfate $\left(3 \mathrm{~g} \mathrm{~L}^{-1}\right)$ previously. The photobioreactors were maintained at $28^{\circ} \mathrm{C}$ with $5.1 \mathrm{mg}$ $\mathrm{L}^{-1}$ dissolved oxygen and a $\mathrm{pH} 7$. The rotifer $B$. rotundiformis used was obtained from strain collection of the laboratory. The experiment they were performed in triplicate and consisted in the control group contained 5 rotifers $\mathrm{mL}^{-1}$, without probiotic bacteria and the treatment group contained 5 rotifers $\mathrm{mL}^{-1}$, with Pseudoalteromonas sp. probiotic bacteria at a concentration of $1.0 \times 10^{3}$ cells $\mathrm{mL}^{-1}$. Each photobioreactor contained an $N$. gaditana microalgae concentration of $7.0 \mathrm{x}$ $10^{6}$ cells $\mathrm{mL}^{-1}$. Rotifers were counted daily, for 8 days to evaluate reproduction, and every 2 days, microalgae and bacteria were counted to ensure maintenance at the initially added concentrations. The counts were performed by normal light microscope (Olympus BX51, Model BX51TF).

To assess duplication of rotifer in larger volumes, two species of rotifers were tested B. plicatilis and B. rotundiformis in triplicate each. They were grown in bags of 500 liters (L) (LDPE sleeves, double background seal, transparent, $150 \mathrm{~cm}$ high $\mathrm{x}$ $180 \mathrm{~cm}$ wide. EROFLEX manufacturer), containing $450 \mathrm{~L}$ of culture medium (seawater chlorinated and neutralized with thiosulfate previously, filtered 0.5 microns/Last ultraviolet radiation, nitrate $0.3825 \mathrm{~g} \mathrm{~L}^{-1}$, phosphate $0.03375 \mathrm{~g} \mathrm{~L}^{-1}$, trace elements $0.2 \mathrm{~mL} \mathrm{~L}^{-1}$, sodium bicarbonate $0.168 \mathrm{~g} \mathrm{~L}^{-1}$ ), previously inoculated with $N$. gaditana $\left(7.0 \times 10^{6}\right.$ cells $\left.\mathrm{mL}^{-1}\right)$. For control and treatment groups the initial inoculum was 10 rotifers $\mathrm{mL}^{-1}$. The probiotic bacteria they were initially inoculated in the bags of the treatment to $1.0 \times 10^{3}$ cells $\mathrm{mL}^{-1}$ after 7 days of initiated the rotifers culturing. Each one day, again the bacteria were inoculated a treatment at a concentration of $1.0 \times 10^{2}$ cells $\mathrm{mL}^{-1}$ to keep concentration of probiotic bacteria. Prior to the administration of the probiotic bacteria, the amounts of microalgae, rotifers and bacteria in each bag, were quantified by normal light microscope (Olympus BX51, Model BX51TF).

\section{Evaluation of Artemia SP. as a probiotic Vector}

Artemia sp. cysts (40 g; Bio-Marine Inc., Hawthorne, CA, USA) were hydrated for an hour in freshwater. After this, the 
cysts were incubated for $24 \mathrm{~h}$ in a photobioreactor (the same systems used for rotifers) with $25 \mathrm{~L}$ of seawater (seawater chlorinated and neutralized with thiosulfate previously, filtered 0.5 microns and was exposed ultraviolet radiation) and the following parameters: $28^{\circ} \mathrm{C}, \mathrm{pH} 7,6 \mathrm{mg} \mathrm{L}^{-1}$ dissolved oxygen, constant aeration, and 2,000 lx. After of incubation, the photobioreactors contents were sieved $(200-100 \mu \mathrm{m})$ to retain hatched nauplii. These were then moved to a clean photobioreactors $(25 \mathrm{~L})$ with $10 \mathrm{~L}$ of seawater with constant aeration. Experiments they were performed in triplicate and consisted in a control group (100 nauplii $\mathrm{mL}^{-1}+1.0 \times 10^{4}$ cell $\mathrm{mL}^{-1} N$. gaditana microalgae $+0.4 \mathrm{~g}$ of Rotinor $\AA / 1,000,000$ nauplii) and a treatment group (100 nauplii $\mathrm{mL}^{1}+1.0 \times 10^{4}$ cell $\mathrm{mL}^{-1} N$. gaditana $+1.0 \times 10^{3}$ cell $\mathrm{mL}^{-1}$ Pseudoalteromonas sp. probiotic bacteria $+0.4 \mathrm{~g}$ of Rotinor ${ }^{\circledR} / 1,000,000$ nauplii). After of $72 \mathrm{~h}$ of incubation was evaluated Artemia survival (\%).

\section{S. LALANDI LARVAE SURVIVAL}

\section{LARVAE OBTENTION}

Experiments were performed at the fish culturing unit of the Universidad de Antofagasta, Chile. The broodstock eggs of the $S$. lalandi were recovered and placed into conic cylindrical tanks $(250 \mathrm{~L})$ with constant aeration, seawater flow, temperature of $21-23^{\circ} \mathrm{C}, \mathrm{pH} 7$ and dissolved oxygen $6 \mathrm{mg} \mathrm{L}^{-1}$. The eggs were counted by volumetric method (number of eggs $\mathrm{mL}^{-1}$ ). These tanks were incubated for approximately two days until larval hatching. The hatched larvae were kept for one additional day in the incubation tank before being counted. The number of larvae (larvae $\mathrm{mL}^{-1}$ ) was obtained from average of three replicates, counting live larvae in $8 \mathrm{~mL}$ of samples coming from a volume of $20 \mathrm{~L}$. Later placed in buckets with seawater (20 L), and transported to culture tanks.

\section{Evaluation of SURVival}

The experiments were performed in triplicate using culture tanks (450 L) containing $300 \mathrm{~L}$ of filtered $(0.45 \mu \mathrm{m})$ seawater with seawater to temperature $21-23^{\circ} \mathrm{C}, \mathrm{pH} 7$, dissolved oxygen 6 $\mathrm{mg} \mathrm{L}^{-1}$, aeration, flow and light constant. An initial inoculum concentration of 10,000 S. lalandi larvae/tank was used. The diet program consisted of two days of feeding with $B$. rotundiformis ( 2 rotifers $\mathrm{mL}^{-1}$ ), followed by feeding B. plicatilis ( 5 rotifers $\mathrm{mL}^{-1}$ ) until day 8 . After, the rotifers were gradually replaced by nauplii Artemia sp. (8-16 nauplii $\left.\mathrm{mL}^{-1}\right)$. For about 5 days it was fed with a mixture of rotifers and artemia. Later, they were fed only Artemia sp. until day 15 that ended the experiment. The experiments consisted of the following: Control $\left(2 \times 10^{5}\right.$ cells $\mathrm{mL}^{-1}$ of the microalgae $N$ gaditana $+B$.
rotundiformis/B. plicatilis rotifers + Artemia nauplii) and Treatment $\left(2 \times 10^{3}\right.$ cells $\mathrm{mL}^{-1}$ probiotic bacteria $+2 \times 10^{5}$ cells $\mathrm{mL}^{-1}$ of the microalgae $N$. gaditana $+B$. rotundiformis / B. plicatilis rotifer + Artemia nauplii).

\section{LARVAE SAMPLING}

After 15 days of culturing, the surviving larvae of $S$. lalandi were collected. In each pond the aeration was cut, this action causes that live larvae tend to rise to the surface, which were carefully collected from the water surface with a cup. These larvae were counted before being transitioned to a new water source. This process was repeated until collect the last larva of each tank. During larvae collection, 20 control and treatment larvae were sampled to measure standard length, which runs from the tip of the mouth to the last bone of the spine or urostylo.

\section{Statistical analysis}

The data were checked for normality and homoscedasticity and analyzed by t-test. The data presented in percentages (survival of Artemia and larvae) were transformed into arcsin function before analysis. The analyses were performed using the GraphPad PRISM 5.0 statistical software (GraphPad Software Inc., San Diego, CA, USA). To evaluate if the duplication of rotifers is related to the presence of probiotic bacteria in the culture, a comparison was made with unidirectional ANCOVA (Microsoft Excel 2010). Besides, the larval growth rate was estimated with the initial and final length of the larvae by adjusting the age-length relationship to a linear regression model, the variables were compared with one-way ANCOVA to establish whether the presence of probiotics significantly affects larval growth. Statistical significance was established at $P<0,05$. Data are presented as values \pm standard error of the mean.

\section{Results}

\section{EFFECTS OF PROBIOtic BACTERIA ON ROtifER REPRODUCTION}

After 3 days of culture in photobioreactors, there was an increase in the concentration of treated rotifers with probiotic bacteria as compared to the control, reaching a concentration of $1.5 \times 10^{7}$ rotifers $\mathrm{mL}^{-1}$, at day 8 of culture (Fig. 1). However, no significant differences were observed between treatment and control ( $\mathrm{t}$-test $=1.639, P=0.1235)$. From these results, it can be deduced that the presence of probiotic bacteria in the culture did not have deleterious effects on the rotifers, nevertheless, there was greater rotifer duplication in cultures with probiotic bacteria. 


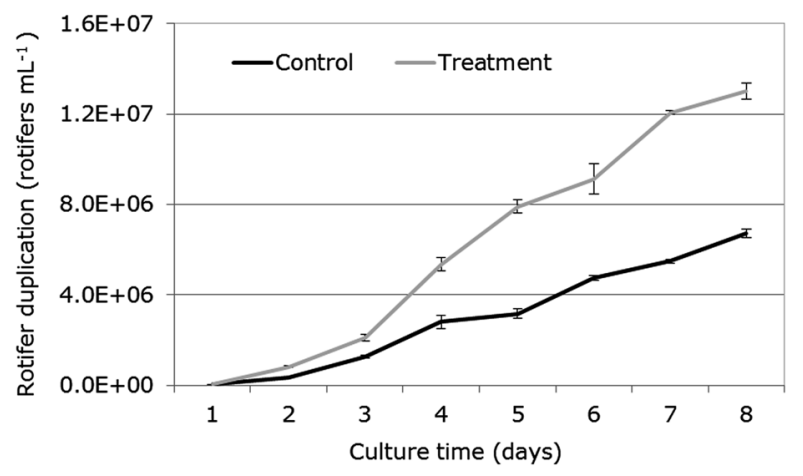

Figure 1. Growth of B. rotundiformis fed with N. gaditana microalgae in photobioreactors. Supplemented with probiotic bacteria (Treatment) and without probiotic bacteria (Control). Bars represent \pm standard error of the mean / Crecimiento de B. rotundiformis alimentado con microalgas N. gaditana en fotobiorreactores. Suplementado con bacterias probióticas (Tratamiento) y sin bacterias probióticas (Control). Las barras representan \pm error estándar de la media
After 5 days of culturing in bags of $450 \mathrm{~L}$, there was an increment in both rotifer duplication, reaching concentrations of $1.47 \times 10^{8}$ rotifers $\mathrm{mL}^{-1}$ for $B$. rotundiformis and $1.49 \times 10^{8}$ rotifers $\mathrm{mL}^{-1}$ for B. plicatilis (Fig. 2), after an initial inoculation de $7.5 \times 10^{6}$ rotifers $\mathrm{mL}^{-1}$. These results indicate the viability of culturing both rotifer species in $450 \mathrm{~L}$ volumes supplemented with probiotic bacteria. With the positive result of ANCOVA analysis of the bacteria-rotifers variables, $B$. rotundiformis (1.28) y B. plicatilis (2.37), it can be deduced that the presence of probiotic bacteria in the culture has a positive relation in the rotifer duplication.

\section{Artemia SP. supplemented with Probiotic}

Artemia sp. nauplius inoculated with bacterial probiotics presented higher survival (90\%) than the control group (75\%) after $72 \mathrm{~h}$ of incubation (Fig. 3). Statistical analyzes showed significant differences (t-test $=3,841, P<0.05$ ) of artemia treated with probiotics compared to controls.

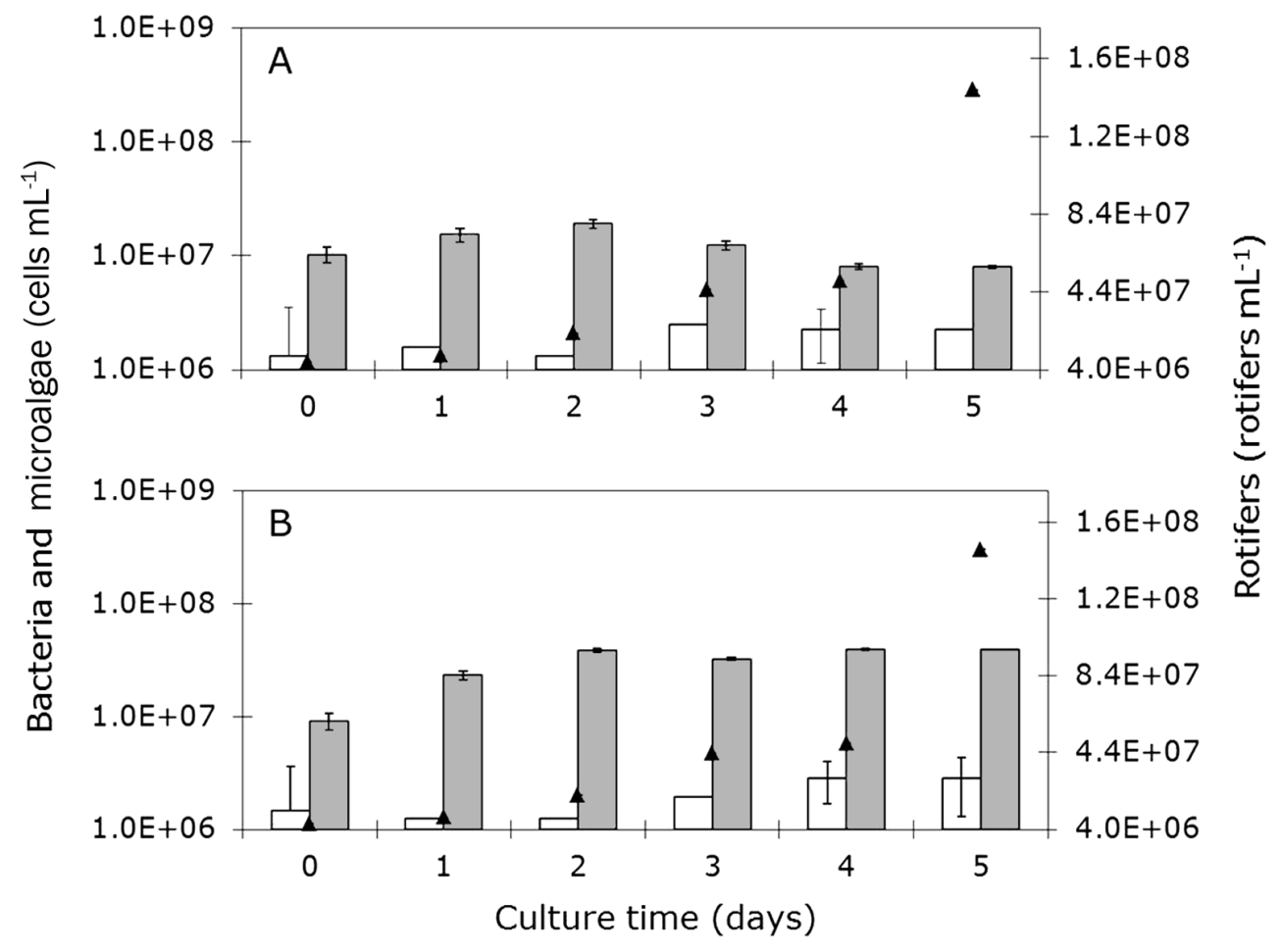

Figure 2. Reproduction of rotifers fed with microalgae and probiotic bacteria cultured in bags of 500 L. A) B. rotundiformis. B) B. plicatilis. White bars indicate bacterial; gray bars indicate microalgae and black triangles indicate rotifer. Bars represent \pm standard error of the mean / Reproducción de rotíferos alimentados con microalgas y bacterias probióticas cultivadas en bolsas de $500 \mathrm{~L}$. A) B. rotundiformis. B) B. plicatilis. Las barras blancas indican bacterias; barras grises indican microalgas; y los triángulos negros indican rotíferos. Las barras representan \pm error estándar de la media 


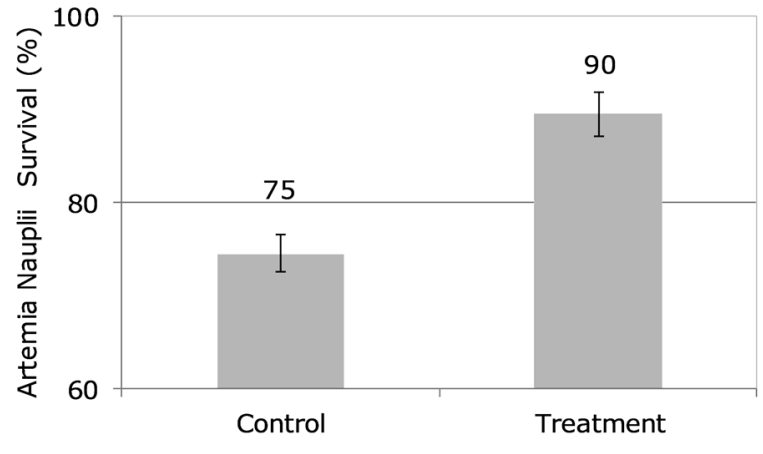

Figure 3. Survival of Artemia sp. nauplii. (Treatment) supplemented with probiotic bacteria and (Control) without probiotic bacteria. Bars represent \pm standard error of the mean / Sobrevivencia de nauplios de Artemia sp. (Tratamiento) suplementado con bacterias probióticas y (Control) sin bacterias probióticas. Las barras representan \pm error estándar de la media

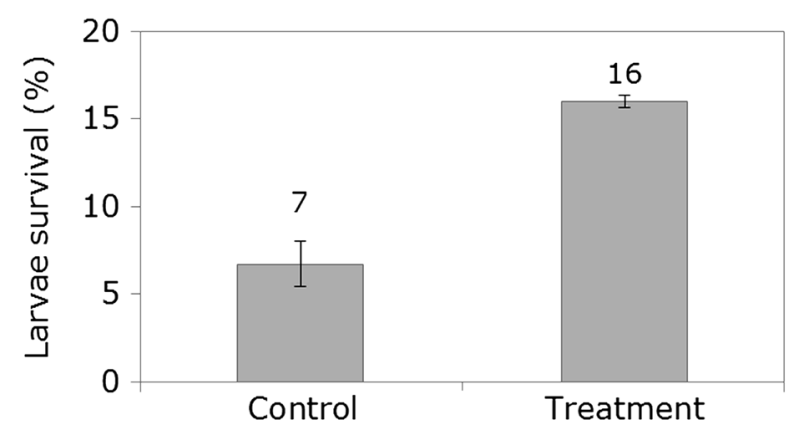

Figure 4. Evaluation of the survival of S. Ialandi larvae fed with probiotics. Supplemented with probiotic bacteria (Treatment) and without probiotic bacteria (Control). Bars represent \pm standard error of the mean / Evaluación de la sobrevivencia de larvas de S. lalandi alimentadas con probióticos. Suplementado con bacterias probióticas (Tratamiento) y sin bacterias probióticas (Control). Las barras representan \pm error estándar de la media

\section{S. LALANDI LARVAE SURVIVAL}

The survival of $S$. lalandi larvae supplemented with probiotic was $16 \%$, more than double that of control larvae with $7 \%$ survival (Fig. 4). The statistical analyzes showed significant differences (t-test $=5.093, P<0.05)$ of the treatment with probiotic respect to the control.

At the end of the experiment (15 days), 20 larvae were sampled at random in treatment and control, and the standard length was measured. The obtained lengths were $7.5 \mathrm{~mm}$ in treatment and $4.4 \mathrm{~mm}$ in length in control. With the length data at the end of the experiment, plus the length measurement of the larvae at the start of the experiment, we estimated the growth rate for the study period and adjusted the data to a linear regression of the age-length relationships. The formulas obtained were Treatment $=1.9+0.373 \mathrm{x}$ and Control $=1.9+0.167 \mathrm{x}$, indicating that growth rates for treatment and control were 0.373 an $0.167 \mathrm{~mm} \mathrm{day}^{-1}$, respectively. The analyses of ANCOVA were positive to variables treatment-control (1.32), agetreatment (7.92) and age-control (3.54). With the estimated daily lengths through linear regression, a t-test analysis was performed, obtaining that the larval survival in treatment was significantly greater than in the control (t-test $=3.179, P<0.05$ ); therefore, the presence of probiotics improve significantly larval growth and survival.

\section{Discussion}

In recent years, the interest in using probiotics in the aquaculture industry has increased due to scientifically supported benefits. According to Martinez et al. (2012), there are various commercial strains of probiotics that contain one or more live microorganisms that can be used to improve the culturing of aquatic organisms, and these can be directly inoculated in the culture or mixed in the feed. The probiotics used in aquaculture must meet certain conditions to prevent any health problems in people. According, Martínez et al. (2012) the probiotics used in animal feed they are Carnobacterium, Alteromonas, Lactobacillus, Streptococcus, Streptomyces, Enterococcus, Micrococcus, Pseudomonas, Roseobacter sp., Saccharomyces, Phaffia, Vibrio, Carnobacterium, Lactococcus, Shewanella, Pediococcus and Bacillus spp. (Leyton \& Riquelme 2010, Avella et al. 2012, Mohapatra et al. 2012).

In relation to the use of Pseudoalteromonas sp. as probiotics, it has been shown that Pseudoalteromonas aliena inhibits the pathogenic Vibrio harveyi (Morya et al. 2014). Furthermore, Longeon et al. (2004) identified the P-153 protein isolated from Pseudoalteromonas sp. X153 as an antibiotic capable of inhibiting bacterial strains of Staphylococcus epidermidis, Propionibacterium acnes, and Propionibacterium granulosum. Contributing to this research, the present study investigated the probiotic potential of Pseudoalteromonas sp. (SLP1), this strain has no haemolytic activity, which makes it a good candidate as probiotic (Sayes et al. 2016). Moreover, this bacterium was isolated directly from S. lalandi, further decreasing the risks of introducing exogenous probiotic strains that could alter the ecosystem. The obtained results revealed that the presence of Pseudoalteromonas sp. (SLP1) probiotic bacteria did not negatively affect rotifers or Artemia sp., even in the volume of $500 \mathrm{~L}$ of culture. The introduction of probiotic Pseudoalteromonas sp. into $S$. lalandi larvae, by using live vectors such as microalgae, rotifers, and Artemia sp. It seems a good alternative to introduce probiotics with life feed for directly delivering to the fish intestine, this allow develop its probiotic activity more efficiently. 
Generally, probiotics have demonstrated promising results in relation to fish growth (Al-Dohail et al. 2009, Sáenz de Rodriguez et al. 2009). Specifically, probiotics improve food digestion and confer protection against harmful bacteria through mechanisms such as competitive exclusion via the production of organic acids, hydrogen peroxide, and various other compounds (Zhou et al. 2009, Rahiman et al. 2010, Abdullah et al. 2011, Youping et al. 2011, Lin et al. 2012, Tapia et al. 2012, Zhang et al. 2012). Additionally, Lobo et al. (2014b) reported that the incorporation of probiotic bacteria during the larval stage of the Solea senegalensis increased survival. The present results of survival evidenced that $S$. lalandi larvae treated with probiotic feed the survived is higher (16\% survival) than those larvae without probiotics (7\% survival). Similarly, those larvae treated with probiotics were longer $(8 \mathrm{~mm})$ than untreated larvae $(4 \mathrm{~mm})$. These results support that probiotics of Pseudoalteromonas sp. (SLP1) can positively affect survival rates and length in fish larvae of $S$. lalandi.

Martínez et al. (2012) argue that technological advances in food production and greater awareness about environmental protection will lead to better aquaculture practices that will ultimately decrease the overexploitation of organisms. One alternative for confronting the diseases present in aquaculture could be the use of non-virulent microorganisms isolated from the microbiota of farmed organisms. Further research is needed to identify if the probiotics present in the microbiota of S. lalandi larvae effectively colonize the digestive tract or if these bacteria are transitory. It is also important evaluate the use of these probiotics on an industrial scale of $S$. lalandi culturing, in addition to considering the economic feasibility of sustained probiotic application. The present results represent a significant advancement towards addressing these remaining doubts, contributing to the optimal larval culturing of S. lalandi.

\section{ACKNOWLEDGEMENTS}

The authors are grateful for the financial support provided by FONDEF Project D10I1050 and D10E1050. In addition, the authors thank the suggestions of the reviewers who allowed to improve this manuscript.

\section{LiTERATURE CITED}

Abdullah AM, R Hashim \& PM Aliyu. 2011. Evaluating the use of Lactobacillus acidophilus as a biocontrol agent against common pathogenic bacteria and the effects on the haematology parameters and histopathology in African catfish Clarias gariepinus juveniles. Aquaculture Research 42: 196209.
Al-Dohail MA, R Hashim \& M Aliyu-Paiko. 2009. Effects of the probiotic, Lactobacillus acidophilus, on the growth performance, haematology parameters and immunoglobulin concentration in African catfish (Clarias gariepinus, Burchell 1822) fingerling. Aquaculture Research 40: 1642 1652.

Avella MA, A Place, SJ Du, E Williams \& S Silvi. 2012. Lactobacillus rhamnosus accelerates Zebrafish backbone calcification and gonadal differentiation through effects on the GnRH and IGF systems. PLoS ONE 7(9): e45572. <doi:10.1371/journal.pone.0045572>

Avilés A \& F Castelló. 2004. Manual para el cultivo de Seriola lalandi (Pisces: Carangidae) en baja California Sur México, 47 pp. Instituto Nacional de la Pesca, Dirección general de la Investigación en Acuacultura, México.

Fernández G, D Cichero, A Patel \& V Martínez. 2015. Genetic structure of Chilean populations of Seriola lalandi for the diversification of the national aquaculture in the north of Chile. Latin American Journal of Aquatic Research 43: 374-379.

Fjellheim AJ, G Klinkenberg, J Skjermo, IM Aasen \& O Vadstein. 2010. Selection of candidate probionts by two different screening strategies from Atlantic cod (Gadus morhua L.) larvae. Veterinary Microbiology 144: 153-159.

Garcés ME, C Sequeiros \& NL Olivera. 2015. Marine Lactobacillus pentosus $\mathrm{H} 16$ protects Artemia franciscana from Vibrio alginolyticus pathogenic effects. International Research 113:41-50.

Hjelm M, O Bergh, A Riaza, J Nielsen, J Melchiorsen, S Jensen, H Duncan, P Ahrens, H Birkbeck \& L Gram. 2004. Selection and identification of autochthonous potential probiotic bacteria from turbot larvae (Scophthalmus maximus) rearing units. Systematic and Applied Microbiology 27:360-371.

Jamali H, A Imani, D Abdollahi, R Roozbehfar \& A Isari. 2015. Use of probiotic Bacillus spp. in rotifer (Brachionus plicatilis) and Artemia (Artemia urmiana) enrichment: Effects on growth and survival of Pacific white shrimp, Litopenaeus vannamei, Larvae. Probiotics and Antimicrobial Proteins 7: 118-125.

Lazado CC, C Marlowe \& A Caipang. 2014. Atlantic cod in the dynamic probiotics research in aquaculture. Aquaculture 424:53-62.

Leyton Y \& C Riquelme. 2010. Marine Bacillus spp. associated with the egg capsule of Concholepas concholepas (common name «Loco») have an inhibitory activity toward the pathogen Vibrio parahaemolyticus. Microbial Ecology 60(3): 599-605.

Lin SH, Y Guan, L Luo \& Y Pan. 2012. Effects of dietary chitosan oligosaccharides and Bacillus coagulans on growth, innate immunity and resistance of koi carp (Cyprinus carpio). Aquaculture 342: 36-41. 
Lobo C, S Tapia-Paniagua, X Moreno-Ventas, FJ Alarcón, C Rodríguez, MC Balebona, MA Moriñigo \& I García de La Banda. 2014a. Benefits of probiotic administration on growth and performance along metamorphosis and weaning of Senegalese sole (Solea senegalensis) Aquaculture 433: 183-195.

Lobo C, X Moreno-Ventas, S Tapia-Paniagua, C Rodríguez, MA Moriñigo \& I García de La Banda. 2014b. Dietary probiotic supplementation (Shewanella putrefaciens Pdp11) modulates gut microbiota and promotes growth and condition in Senegalese sole larviculture. Fish Physiology and Biochemistry 40: 295-309.

Longeon A, J Peduzzi, M Barthelemy, S Corre, JL Nicolas \& M Guyot. 2004. Purification and partial identification of novel antimicrobial protein from marine bacterium Pseudoalteromonas sp. strain X153. Marine Biotechnology 6: 633-641.

Martínez P, AL Ibáñez, O Monroy-Hermosillo \& H Ramírez-Saad. 2012. Use of probiotics in Aquaculture. ISRN Microbiology 2012, 916845, <doi:10.5402/2012/ 916845>

Mohapatra S, T Chakraborty, AK Prusty, PDas, PK Prasad \& KN Mohanta. 2012. Use of different microbial probiotics in the diet of rohu (Labeo rohita) fingerlings: effect on growth, nutrient digestibility and retention, digestive enzyme activities and intestinal microflora. Aquaculture Nutrition 18: $1-11$.

Morya VK, W Choi \& EK Kim. 2014. Isolation and characterization of Pseudoalteromonas from fermented Korean food, as an antagonist to Vibrio harveyi. Applied Microbiology and Biotechnology 98: 1389-1395.

Newaj-Fyzul A \& B Austin. 2015. Probiotics, immunostimulants, plant products and oral vaccines, and their role as feed supplements in the control of bacterial fish diseases. Journal of Fish Diseases 38: 937-955.
Rahiman KMM, Y Jesmi, AP Thomas \& AAM Hatha. 2010. Probiotic effect of Bacillus NL110 and Vibrio NE17 on the survival, growth performance and immune response of Macrobrachium rosenbergii (de Man). Aquaculture Research 41: 120-134.

Sáenz de Rodriguez MA, P Diaz-Rosales, M Chabrillon, H Smidt, S Arijo \& JM Leon-Rubio. 2009. Effect of dietary administration of probiotics on growth and intestine functionally of juvenile Senegalese sole (Solea senegalensis, Kaup 1858). Aquaculture Nutrition 15: 177-185.

Sayes C, Y Leyton \& C Riquelme. 2016. Bacteria Pseudoalteromonas sp. potencial probiótico para cultivos larvales de peces. Latin American Journal of Aquatic Research 44(1): 76-84.

Silva-Aciares F \& C Riquelme. 2008. Comparisons of the growth of six diatom species between two configurations of photobioreactors. Aquacultural Engineering 38: 26-35.

Tapia PA, RP Diaz \& RJ Leon. 2012. Use or the probiotic Shewanella putrefaciens Pdp11 on the culture of Senegalese sole (Solea senegalensis, Kaup 1858) and gilthead seabream (Sparus aurata L). Aquaculture International 21: 1-15.

Youping Y, M Dongdong, L Shijiang \& W Zhongkang. 2011. Effects on growth and digestive enzyme activities of the Hepialus gonggaensis larvae caused by introducing probiotics. World Journal of Microbiology and Biotechnology 27:529-533.

Zhang S, Y Sing, M Long \& Z Wei. 2012. Does dietary administration of Lactococcus lactis modulate the gut microbiota of grouper (Epinephelus coioides). Journal of the World Aquaculture Society 43: 198-207.

Zhou XX, YB Wang \& WF Li. 2009. Effect of probiotic on larvae shrimp (Penaeus vannamei) based on water quality, survival rate and digestive enzyme activities. Aquaculture 287:349-353 